\title{
Indian childhood cirrhosis: an inherited disorder of tryptophan metabolism?
}

\author{
A M SUR, ANJANA BHATTI
}

British Medical fournal, 1978, 2, 529-531

\section{Summary and conclusions}

Urine samples from members of 29 families of patients with Indian childhood cirrhosis (ICC) and nine families with related disorders gave positive reactions when tested with ferric chloride. Column chromatography showed that this was due to the presence of abnormally large amounts of tryptophan metabolites, notably 3-hydroxyanthranilic acid. Affected pedigrees had a significantly greater prevalence of peptic ulcer, adult cirrhosis, diabetes mellitus, migraine, and Parkinsonism than a control population.

ICC may result from an inborn error of tryptophan metabolism in susceptible ethnic groups.

\section{Introduction}

Indian childhood cirrhosis (ICC) is one of the most challenging paediatric problems in India. A condition with features of the disease, including fetor hepaticus, was first described by Susruta around 1000 BC. ${ }^{1}$ It is commonly familial and has a predilection for certain ethnic subgroups and occurs more often in boys and in a specific age group, usually $1 \frac{1}{2}-3$ years; the mortality rate is very high. It begins with hepatosplenomegaly or vague symptoms including irritability and loss of appetite or at times excessive appetite and goes on to ascites and jaundice. ${ }^{2-1}$ Histologically, the disease is characterised by almost complete absence of regeneration, "creeping-in fibrosis" leading to separation of individual or groups of liver cells, and severe degenerative changes in the hepatocytes. ${ }^{5} 6$

Ethnic subgroups predominantly affected are the Brahmins, Kayasthas, Agrawals, Rajputs, and Sikhs. ${ }^{34}$ Most of these have descended from what is traditionally the higher strata of Hindu society.

The cause of ICC has been variously attributed to transplacentally transmitted hepatitis, ${ }^{7}$ hepatic damage due to aflatoxins in foodstuffs, ${ }^{8}$ low serum zinc concentrations, ${ }^{9}$ hepatitis in early life, ${ }^{1011}$ and autoimmune disease..$^{12} \mathrm{We}$ found that the urine of patients and their parents consistently and immediately turned brown when tested with ferric chloride. 3-Hydroxyanthranilic acid (3-HAA), acetoacetic acid, and vanillic acid cause this reaction, while urine containing xanthurenic acid turns green or, after a delay, greenish brown. The last three were excluded by appropriate tests, and it appeared that 3-HAA (a metabolite on the tryptophan-niacin pathway) was probably responsible. Column chromatography substantiated this. In some cases the reaction occurred only after a loading dose of tryptophan.

We decided to investigate tryptophan metabolism, and, as

Government Medical College, Nagpur, India

A M SUR, FRCPED, DCH, professor and head of department of paediatrics

Luton and Dunstable Hospital, Luton, Bedfordshire LU4 ODZ ANJANA BHATTI, MD, DCH, paediatric registrar there was an increased prevalence of other diseases in the pedigrees of children with cirrhosis, also sought information on these in some of the families.

\section{Patients and methods}

The diagnosis of ICC was based on clinical criteria, supported in 20 patients by liver biopsy. In a further nine biopsy was either not permitted or not considered safe because of advanced disease and the diagnosis was based on firm clinical grounds, ethnic background, and a history of several cases in the family. Among the 29 families 23 probands were alive and six were dead when the metabolic studies were undertaken.

Nine families of patients with the following additional disorders were studied: peptic ulcer (2), bronchial asthma (3), carcinoma of the bladder (2), and migraine (2). Twenty-five random pedigrees of healthy schoolchildren matched for age and providing a total of 1002 subjects served as controls.

A $5 \mathrm{ml}$ urine sample was acidified to $\mathrm{pH} 6$ with a few drops of $0.5 \mathrm{~N} \mathrm{HCl}$, and three drops of freshly prepared $10 \%$ ferric chloride solution were added. An immediate change to brown that persisted on boiling was taken as a positive reaction. Column chromatography was carried out on 24-hour urine collections by the method of Price et al, ${ }^{14}$ 3-HAA being measured in both $\mathrm{C}$ and $\mathrm{D}$ fractions. ${ }^{15}$ Xanthurenic acid was estimated by the method of Wachstein and Gadaitis. ${ }^{16}$

Excretion of metabolites of tryptophan was examined in 10 healthy adults of both sexes; nine healthy children of both sexes and matched for age; 39 parents of children with ICC; 12 children with ICC; and three out of eight adults with cirrhosis of unknown cause.

A low tryptophan diet, oral vitamin $B_{6}$ in massive doses (1-1.5 g/ day), and early and vigorous treatment of infections were the mainstays of treatment. Corticosteroids were used judiciously. Foodstuffs with a tryptophan content exceeding $2.9 \mathrm{nmol} / \mathrm{kg}(0.06 \mathrm{mg} / 100 \mathrm{~g})$ were prohibited, while those with a content of less than $2 \cdot 0 \mathrm{nmol} / \mathrm{kg}$ $(0.04 \mathrm{mg} / 100 \mathrm{~g})$ were freely allowed. Subjects without liver disease underwent loading tests with L-tryptophan, $2 \mathrm{~g}$ being given to adults and $500 \mathrm{mg}$ to infants.

Results were analysed by Student's $t$ test and, when necessary, the non-parametric $U$ test.

\section{Results}

CLINICAL

The 29 patients comprised 9 Agrawals, 7 Brahmins, 4 Jains, 3 Scheduled Castes, 2 Kayastha, 2 Kunbi, 1 Rajput, and 1 Sikh. A significantly greater prevalence of peptic ulcer, diabetes mellitus, Parkinsonism (mean age at onset 35 years), adult cirrhosis, and migraine was found in families of patients with ICC than in the controls (table I). The prevalence of chronic nephropathy, chronic urticaria, and asthma was also increased in some families but not significantly so. Seven families $(24 \%)$ had a total of 10 close relatives who had had hepatomegaly with or without ascites in early childhood but had fully recovered. Four children affected when over 5 years of age and in whom the diagnosis had been made two to five years before and confirmed by biopsy appeared to be fully recovered.

\section{BIOCHEMICAL}

The ferric chloride test produced a positive response in all 23 patients with ICC tested and in 23 of the 25 pairs of parents available for testing. The proportions of siblings and more-distant relatives with positive responses were smaller but still remarkably high (table II). 
TABLE I-Prevalence of diseases in different pedigrees per 100 subjects. $P$ values are significance of differences from controls

\begin{tabular}{|c|c|c|c|c|c|c|c|c|c|}
\hline & \multicolumn{2}{|c|}{$\begin{array}{l}\text { ICC (10 pedigrees; } 403 \\
\text { subjects })\end{array}$} & \multicolumn{2}{|c|}{$\begin{array}{c}\text { Bronchial asthma (2 pedigrees; } \\
130 \text { subjects) }\end{array}$} & \multicolumn{2}{|c|}{$\begin{array}{l}\text { Peptic ulcer (2 pedigrees; } 55 \\
\text { subjects) }\end{array}$} & \multicolumn{2}{|c|}{$\begin{array}{l}\text { Carcinoma of bladder } \\
\text { (1 pedigree; } 43 \text { subjects) }\end{array}$} & \multirow{2}{*}{$\begin{array}{l}\text { Prevalence in } \\
\text { controls ( } 25 \\
\text { pedigrees; } \\
1002 \text { subjects }\end{array}$} \\
\hline & Prevalence & $\mathbf{P}$ & Prevalence & $\mathbf{P}$ & Prevalence & $\mathbf{P}$ & Prevalence & $\mathbf{P}$ & \\
\hline $\begin{array}{l}\text { Bronchial asthma } \\
\text { Peptic ulcer } \\
\text { Migraine } \\
\text { ICC } \\
\text { Diabetes mellitus } \\
\text { Adult cirrhosis ... } \\
\text { Parkinsonism .. } \\
\text { Malignant disease }\end{array}$ & $\begin{array}{l}1 \cdot 5 \\
4 \\
1 \\
7 \\
4 \\
1 \\
1 \\
0 \cdot 5\end{array}$ & $\begin{array}{l}<0.001 \\
<0.05 \\
<0.001 \\
<0.001 \\
<0.05 \\
<0.01 \\
>0.5\end{array}$ & $\begin{array}{l}7 \cdot 7 \\
2 \cdot 3 \\
0 \cdot 77 \\
2 \cdot 3 \\
0 \cdot 77 \\
0 \\
0 \\
0\end{array}$ & $\begin{array}{l}<0.001 \\
<0.01 \\
>0.5 \\
<0.001 \\
>0.5 \\
>0.05\end{array}$ & $\begin{array}{l}9.09 \\
5.45 \\
1.82 \\
5.45 \\
1.82 \\
1.82 \\
1.82 \\
1.82\end{array}$ & $\begin{array}{r}<0.001 \\
<0.001 \\
>0.01 \\
<0.001 \\
>0.1 \\
>0.1 \\
<0.05 \\
>0.1\end{array}$ & $\begin{array}{l}2 \cdot 32 \\
0 \\
0 \\
0 \\
0 \\
0 \\
0 \\
9 \cdot 2\end{array}$ & $<0.001$ & $\begin{array}{l}0 \cdot 9 \\
0 \cdot 2 \\
0 \cdot 1 \\
0 \\
1 \\
0 \cdot 1 \\
0 \\
0 \cdot 4\end{array}$ \\
\hline
\end{tabular}

All children and parents in the peptic ulcer and bronchial asthma subgroups gave positive responses to the test, as did one of the two patients with carcinoma of the bladder and both patients with migraine, together with some of their normal children; in one case of migraine, specimens from both children were positive. Two of the eight patients with adult cirrhosis gave positive responses. In normal subjects ( 400 children and 200 adults) the overall incidence of positive responses was $6 \%$; in Brahmins and Agrawals the incidences were $25 \%$ and $30 \%$ respectively.

TABLE II-Results of ferric chloride tests

\begin{tabular}{|c|c|c|c|c|c|c|}
\hline & & \multirow{2}{*}{$\begin{array}{l}\text { Patients } \\
\text { with ICC }\end{array}$} & \multicolumn{2}{|c|}{$\begin{array}{l}\text { Parents of children } \\
\text { with ICC }\end{array}$} & \multirow{2}{*}{$\begin{array}{l}\text { Siblings of } \\
\text { father or } \\
\text { mother or } \\
\text { both }\end{array}$} & \multirow{2}{*}{$\begin{array}{l}\text { Patients' } \\
\text { siblings }\end{array}$} \\
\hline & & & Pairs & Singles & & \\
\hline $\begin{array}{l}\text { No tested } \\
\text { No positive }\end{array}$ & 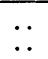 & $\begin{array}{l}23 \\
23\end{array}$ & $\begin{array}{l}25 \\
23\end{array}$ & $\begin{array}{l}3 \\
3\end{array}$ & $\begin{array}{l}8 \\
6\end{array}$ & $\begin{array}{l}16 \\
14\end{array}$ \\
\hline
\end{tabular}

Patients with ICC excreted significantly greater amounts of tryptophan metabolites than normal children (table III), particularly 3-HAA $(P<0.001)$. Other metabolites significantly increased were anthranilic acid glucuronide, orthoaminohippuric acid, acetylkynurenine, kynurenine, and xanthurenic acid-all $\mathrm{P}<0.01$-and 3-hydroxykynurenine $(P<0.05)$. Eleven of the 12 patients studied excreted abnormal amounts of two or more metabolites including 3-HAA, and most five or six.

Parents of children with ICC also excreted highly significantly greater amounts of 3-HAA than normal adults $(P<0.001$-table IV), and significantly greater amounts of kynurenine and xanthurenic acid $(P<0.05)$. Three-quarters of the parents excreted 3-HAA in abnormal amounts, and two-thirds excess kynurenine also.

All patients except one in the associated disorders group excreted excess 3-HAA, and other metabolites appeared in the urine occasionally. The three patients with adult cirrhosis who were tested, however, differed from normal only in excreting excessive amounts of xanthurenic acid. Post-treatment levels of metabolites studied in 3 cases were about $50 \%$ of initial levels, though still very much raised above normal.

\section{TREATMENT}

Five patients with advanced ICC greatly improved with treatment but five to seven months later developed lung infections without hepatic coma and died. A girl with early changes was well after 20 months, three serial biopsies showing an arrest of histological changes; and a patient with peptic ulcer had clinically improved.
TABLE IV-Excretion of tryptophan metabolites ( $\mu$ mol/kg/24 h) before and after loading doses of laevo-tryptophan in normal adults and parents of children . with ICC. Figures are means $\pm S D$ (numbers tested given in parentheses)

\begin{tabular}{|c|c|c|c|c|}
\hline & & Normal adults & $\begin{array}{l}\text { Parents of children } \\
\text { with ICC }\end{array}$ & $\mathbf{P}$ \\
\hline $\begin{array}{l}\text { AAG } \\
\text { OAHA } \\
\text { AK } \\
\text { KYN } \\
\text { 3-HAA } \\
\text { 3-HK } \\
\text { XA* }^{*}\end{array}$ & $\begin{array}{l}\left\{\begin{array}{l}\text { Before } \\
\text { After } \\
\text { Before } \\
\text { After } \\
\text { Before } \\
\text { After } \\
\text { Before } \\
\text { After } \\
\text { Before } \\
\text { After } \\
\text { Before } \\
\text { After } \\
\text { Before }\end{array}\right.\end{array}$ & $\begin{array}{c}0.149 \pm 0.228(10) \\
0.21 \pm 0.224(9) \\
0.169 \pm 0.199(10) \\
0.15 \pm 0.132(9) \\
0.228 \pm 0.32(10) \\
0.5 \pm 0.582(9) \\
0.63 \pm 0.78(9) \\
0.53 \pm 0.427(8) \\
1.38 \pm 0.847(10) \\
2.12 \pm 0.739(9) \\
0.795 \pm 0.745(7) \\
1.36 \pm 0.94(6) \\
0.99 \pm 0.97(10)\end{array}$ & $\begin{array}{c}0.134 \pm 0.135(38) \\
0.15 \pm 0.137(25) \\
0.174 \pm 0.27(39) \\
0.16 \pm 0.26(25) \\
0.76 \pm 1.905(38) \\
0.88 \pm 1.985(25) \\
2.67 \pm 3.78(39) \\
3.8 \pm 12.3(25) \\
3.8 \pm 2.08(39) \\
5.476 \pm 2.29(25) \\
1.64 \pm 1.96(39) \\
1.79 \pm 2.77(25) \\
3.7 \pm 3.3(28)\end{array}$ & $\begin{array}{l}>0.05 \\
>0.05 \\
>0.05 \\
>0.05 \\
>0.05 \\
>0.05 \\
<0.05 \\
>0.05 \\
<0.001 \\
<0.001 \\
>0.05 \\
>0.05 \\
<0.001\end{array}$ \\
\hline
\end{tabular}

*Key to abbreviations given in table III.

\section{Discussion}

Tryptophan metabolism appears to be altered in patients with ICC, as well as in their parents and close relatives. The presence $\bar{D}$ of this defect in asymptomatic relatives shows that it is not a $\frac{\varnothing}{\otimes}$ result of the liver disease. The most important abnormality is $\varrho$ the excretion of large amounts of 3-HAA, though other $\overrightarrow{\overrightarrow{0}}$ metabolites are also found in excess (table III and IV). The 3 basic defect may be a deficiency of 3-hydroxyanthranilic oxidase with accumulation of precursors of 3-HAA on the? tryptophan-niacin pathway, which are broken down by other enzymes.

We found an increased prevalence of peptic ulcer in the pedigrees of patients with ICC. An association between peptic 3 ulcer and cirrhosis has been reported in $11.3-18 \%$ of cases in $\delta$ clinical and necropsy studies. ${ }^{171819}$ This may not be coincidental 3 but be due to a possible genetic interrelation between the two 응 and the result of a common underlying metabolic defect. The reported association between cirrhosis and diabetes mellitus 2021 o agrees with our finding of an increased prevalence of diabetes $\frac{?}{2}$ mellitus in the pedigrees affected by ICC.

We believe that ICC belongs to the group of inherited $\mathbb{O}$ disorders of tryptophan metabolism. The target organ may vary and depend on genetic or environmental factors or both. The high familial incidence, similarity in diet, and specific age

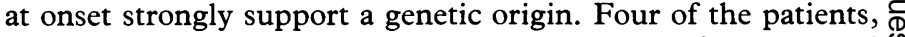
who were affected by cirrhosis when over the age of 5 , recovered $\stackrel{\oplus}{+}$ spontaneously. Onset in infancy with a high mortality, onset in

TABLE III-Excretion of tryptophan metabolites ( $\mu$ mol/kg/24 h) in normal children and patients with ICC. Figures are means \pm SD (numbers of subjects $\underset{0}{\sigma}$ tested given in parentheses)

\begin{tabular}{|c|c|c|c|c|c|c|c|}
\hline & AAG & OAHA & $\mathrm{AK}$ & $\mathrm{KYN}$ & 3-HAA & 3-HK & $\mathrm{XA}$ \\
\hline $\begin{array}{l}\text { Normal children } \\
\text { Patients with ICC }\end{array}$ & $\begin{array}{r}0.196 \pm 0.22(9) \\
1.9 \pm 1.5(12) \\
\end{array}$ & $\begin{array}{r}0.275 \pm 0.299(9) \\
1.6 \pm 1.22(12) \\
\end{array}$ & $\begin{array}{l}0.91 \pm 1.05(9) \\
5 \cdot 17 \pm 4.28(12) \\
\end{array}$ & $\begin{array}{r}1.076 \pm 2.35(6) \\
8.06 \pm 5.23(11) \\
\end{array}$ & $\begin{array}{r}5 \cdot 34 \pm 3 \cdot 4(9) \\
24 \cdot 51 \pm 12 \cdot 37(11) \\
\end{array}$ & $\begin{array}{r}1 \cdot 52 \pm 4 \cdot 23(9) \\
12 \cdot 96 \pm 14 \cdot 7(11) \\
\end{array}$ & $\begin{array}{c}0.86 \pm 0.68(5) \\
18.91 \pm 7.67(11) \\
\end{array}$ \\
\hline $\mathbf{P}$ & $<0.01$ & $<0.01$ & $<0.01$ & $<0.01$ & $<0.001$ & $<0.05$ & $<0.01$ \\
\hline
\end{tabular}
AAG $=$ Anthranilic acid glucuronide. OAHA $=$ Orthoaminohippurate. $A K=$ Acetylkynurenine. $\mathrm{KYN}=\mathrm{Kynurenine} .3-\mathrm{HAA}=3-\mathrm{Hydroxyanthranilate.} \mathrm{3-HK=3-Hydroxy-}$
kynurenine. $\mathrm{XA}=\mathrm{X}$ anthurenate. 
older children with recovery, and late occurrence as adult cirrhosis may be the manifestations of an age-related variability in the expression of an abnormal gene.

Results of the ferric chloride test were positive in two of the eight patients with adult cirrhosis, and, though only xanthurenic acid excretion was significantly increased in the three patients tested, one belonging to a susceptible ethnic subgroup excreted other metabolites on the pattern of ICC. An increased prevalence of adult cirrhosis was also noted in the pedigrees of patients with ICC. A common metabolic defect may underlie both types of cirrhosis, particularly in susceptible ethnic groups.

The most probable mode of inheritance appears to be through an autosomal dominant gene of intermediate dominance with diminished expressivity and at times reduced penetrance in girls. Given a positive family history, children who excrete abnormally large amounts of two or more of the six metabolites, one of which must be 3-HAA, should be considered at risk. Adults excreting 3-HAA with or without kynurenine may be carriers. But about a quarter of adult carriers and some $10 \%$ of children liable to suffer from ICC cannot be detected. With early diagnosis it may be possible to arrest the disease with a low tryptophan diet and massive doses of vitamin $B_{6}$. Larger trials earlier in the disease are needed.

The association of ICC with an increased prevalence of peptic ulcer, asthma, diabetes, and migraine in the pedigrees may point to a genetic interrelation among these disorders, and this needs further study.

We gratefully acknowledge the following for their help: Drs $\mathrm{C} \mathrm{H}$ Chakraborty, N B Akarte, and Shastri, of the department of biochemistry, Nagpur University; Miss S Mitra, M Kejdiwal, Mrs P Pradhan, Kalraya, A Raut, K P Zunke, and B K Joshirao; Drs J N Rao, V Keshwani, S Sardeshpande, Vilhekar, and M Dixit; P K Mehta (spectrophotometry), Dr S N Sangal, R D Majumdar (statistics), Dr S Grover (histopathology), and Mrs Sobita
Sur; and the dean of the Government Medical College, Nagpur, for permission to publish. This paper is based on one read at the International Symposium of the International College of Pediatrics, Helsinki, June 1978.

\section{References}

${ }^{1}$ Susruta, Susruta Samhita, Uttar tantra, ch 27, verse 15. Kanpur, India, Saraswati Pustakalaya, 1952

${ }^{2}$ Liver Diseases Sub-committee, Indian Council of Medical Research, Indian fournal of Medical Research, 1955, 43, 723.

${ }^{3}$ Khanna, K K, Indian fournal of Pediatrics, 1968, 35, 285

4 Majumdar, D K, Kapoor, V K, and Sharma, N L, Indian fournal of Pediatrics, 1969, 6, 753.

${ }^{5}$ Patel, B D, Parekh, S R, and Chitale, A R, Indian fournal of Pediatrics, 1974, 11, 19.

${ }^{6}$ Aikat, B K, Bhattacharya, I, and Walia, B N, Indian fournal of Medical Research, 1974, 62, 953.

${ }^{7}$ Aikat, B K, and Sengupta, K P, Indian fournal of Medical Research, 1956, 10, 169.

8 Amla, I, et al, Indian fournal of Pediatrics, 1970, 7, 267.

9 Ghai, O P, and Vasuki, K, Indian fournal of Pediatrics, 1971, 8, 309.

${ }^{10}$ Chandra, R K, Lancet, 1970, 1, 537.

11 Sunderavalli, N, et al, Indian fournal of Pediatrics, 1971, 8, 365.

12 Prasad, P, British Medical fournal, 1962, 2, 1031.

${ }^{13}$ Dixit, S K, and Gupta, R C, Indian fournal of Pediatrics, 1970, 17, 324

${ }^{14}$ Price, J N, Brown, R R, and Yess, N, Advances in Metabolic Disorders, $1965,2,159$.

15 Michael, A F, et al, fournal of Clinical Investigation, 1964, 43, 159.

${ }^{16}$ Wachstein, M, and Gadaitis, A, American fournal of Clinical Pathology, 1952, 22, 652 .

17 Tabaqchali, S, and Dawson, A M, Gut, 1964, 5, 417.

${ }^{18}$ Fainer, D C, and Halstead, J A, Fournal of the American Medical Association, 1955, 157, 413 .

9 Lipp, W F, and Williams, R H, Gastroenterology, 1948, 22, 181.

${ }^{20}$ Schiff, L, Diseases of the Liver, p 695. Philadelphia and Toronto, Lippincott, 1969.

21 Jacques, W E, New England fournal of Medicine, 1953, 249, 442.

\title{
HBsAg-positive chronic liver disease : inhibition of DNA polymerase activity by vidarabine
}

\author{
R G CHADWICK， M F BASSENDINE， E M CRAWFORD， H C THOMAS， S SHERLOCK
}

British Medical fournal, 1978, 2, 531-533

\section{Summary and conclusions}

Four patients who had chronic liver disease and were positive for hepatitis $B$ surface antigen (HBsAg) were treated with vidarabine, a synthetic purine nucleoside that inhibits DNA polymerase activity in vitro and in vivo. Before treatment all had raised serum DNA polymerase concentrations. Three also had hepatitis $B$ e (HBe) and were shown by electron microscopy to have hepatitis B virus (Dane) particles in their serum. In all patients 10 days' treatment with vidarabine resulted in an immediate loss of DNA polymerase activity. In three

Department of Medicine, Royal Free Hospital, London NW3 2QG R G CHADWICK, MA, MRCP, research fellow

M F BASSENDINE, BSC, MRCP, H A M Thompson research fellow

E M CRAWFORD, research assistant

H C THOMAS, PHD, MRCP, lecturer in medicine

S SHERLOCK, MD, FRCP, professor of medicine patients the activity returned when treatment was stopped. In those three patients Dane particles and $\mathrm{HBe}$ antigen persisted during and after treatment; in the fourth patient, who remained negative for DNA polymerase, HBsAg titres fell.

Although vidarabine inhibited virus replication, virus particles did not disappear from the blood in these patients, presumably because the particles were cleared only slowly. Similar results with interferon suggest that the virus disappears, and HBsAg titres fall, some weeks after the fall in DNA polymerase activity. Continued treatment may therefore have a sustained effect on viral replication. Whether vidarabine can permanently clear HBsAg and so arrest chronic liver disease remains to be seen, but at the very least it could reduce the spread of infection.

\section{Introduction}

Vidarabine (adenine arabinoside) is a synthetic purine nucleoside with antiviral activity against a broad group of DNA-containing viruses and some RNA tumour viruses. ${ }^{1}$ It is relatively nontoxic, ${ }^{2}$ probably does not affect cellular or humoral immune 